\title{
アルゴンレーザーによる殺菌のメカニズム \\ Mechanism of Bacteriocidal effect by Argon laser
}

\author{
岡崎 辰也 \\ 大阪医科大学整形外科学教室 \\ T569 大阪府高栶市大学町 $2-7$ \\ TEL $0726-83-1221$ FAX $0726-83-6265$
}

\section{TATSUYA Okazaki}

Department of Orthopedic Surgery, Osaka Medical College 2-7 Daigaku-cho, Takatsuki City Osaka Pref.

\section{要 旨}

黄色ブドウ球菌をはじめとするブドウ球菌, 大晹菌, 緑膿菌や他の細菌についてのレーザー による殺菌効果に関する報告はいくらかみら的るが、レーザーによる殺菌効果のメカニズム に関しては明らかではない。本実験に㧍いて著者は，アルゴンレーザーによる殺菌効果のメ カニズムについて次のような方法を用いて調べた。

a．アルゴンレーザーによる殺菌効果について增殖阻止域の形成の有無を観察することに より調べた。

b．MRSAをはじめよする5 種類の細菌に対してレーザーを照射し，殺菌に有効な照射 出力と照射時間との関係を調べた。

c.レーザー照射後のMRSAの形態学的变化について透過型電子顕微鏡を用いて観察し た。その対照として、レーザー非照射菌、紫外線を照射した細菌、熱処理した細菌もあ わせて観察した。

d．アクリジンオレンジにより細菌を染色しレレーザー照射群と非照射群との間の蛍光性 の違いを蛍光顕微鏡を用いて観察した。

e 、レーザー照射後のMRSAのDNA变化をアガロースゲル電気泳動を用いて観察した。 以上の実験より

a.アルゴンレーザーによりすべての細菌について增殖阻止域の形成を認めた。

b. 照射出力と照射時間とを変化させたところ殺菌効果の出現と照射出力との間には深い 関係があり、また緑䐬菌では他の細菌と比べてアルゴンレーザーにより殺菌され易かっ た。

c.アルゴンレーザー照射後, 細菌の細胞質および核様体付近では電子密度が上昇してい た。その变化は細菌孝熱処理したものと非常に類似していた。

d.レーザー照射前後で細菌のアクリジンオレンジの蛍光性に变化はなかった。

e.レーザー照射前後で電気泳動上，細菌のDNAのバンドパターンに变化はなかった。

以上よりアルゴンレーザーによるMRSAに対する殺菌効果は, 光化学的作用よりも熱作

(平成 7 年 8 月 24 日受理, 平成 7 年12月2 日掲載決定)

(Received August 24th 1995, Accepted December 2nd 1995) 
用が主体であると考えられ。またアルゴンレーザーは細菌のDNAのバンドパターンには直接

影響を及ばさないことがわかった。

キーワード：アルゴンレーザー，殺菌効果，透過型電子顕微鏡．電気泳動法，核酸

\begin{abstract}
Bactericidal effects by laser irradiation on Staphylococcus aureus, Escherichia coli, Pseudomonas aeruginosit and other bacterial strains have been reported by some researchers, but little attention has been given to the bactericidal mechanism by laser irradiation. In this report, bactericidal mechanism using Argon laser was examined by means of the following method.
\end{abstract}

a. Bactericidal effects by Argon laser were evaluated by the formation of growthinhibitory circle of bacteria.

b. The relationship between irradiation output and irradiation time of Argon laser was examined in 5 bacteria including MRSA.

c. The morphological changes in MRSA after laser irradiation were observed by using the transmission electron microscope. As controls, non-irradiated bacteria, heat-treated bacteria and ultraviolet irradiated bacteria were also observed.

d. The bacterial colony were irradiated by laser. The bacteria were stained with acridine orange, and then were compared with non-irradiated bacteria by observing with fluorescence microscope.

e. Change of DNA by laser irradiation on MRSA was studied using Agarose gel electrophoresis.

The results of the experiments were as follows.

a. All bacteria showed a growth inhibitory circle after laser irradiation.

b. By changing irradiation output and irradiation time, we found that there was a close relationship between the total energy per unit area and the appearance of a bactericidal effect, and that Pseudomonas aeruginosa had high sensitivity to the Argon laser compared with other bacteria.

c. The cytoplasm and nucleoid of the bacteria were seen to be higher electron dense lesion. These feature was in good agreement with the image of the cytoplasm of bacteria after heating.

d. After irradiation, fluorescence which acridine orange emitted did not presented difference between irradiated group and non-irradiated group.

e. DNA band pattern of MRSA on electrophoresis was not changed after laser irradiation.

In this study, it is suggested that the bactericidal effects on MRSA by Argon laser may be caused mainly by heat rather than photo-dynamic action and that laser may not directly influence band pattern of the DNA in bacteria.

Key words, Argon laser, Bactericidal effect, transmission electron microscope, electrophoresis, DNA 


\section{緒 言}

近年,メチシリン耐性黄色ブドウ球菌（MRSA）に よる感染症に対して臨床上大きな関心が害せら扟ている。 その理由は，大病院にて分離される黄色ブドウ球菌のう ち40〜70\%はメチシリンをはじめとするペニシリン系抗 生物筫也第一世代，第二世代のセフェム系抗生物筫にも 耐性を有し，現時点に执いて十分な治療法か確立してお らず，兔疫機構の低下している患者に执いては時上して 致命的な状態をひきおこす可能性があるからである。今 後，新たに感受性の高い抗生物質か開発されたとしても 再び耐性を獲得することにより治療が困難となること予 想されるため。抗生物質による化学療法以外の治療法に ついても検討する必要があると考えた。

一方，1960年にレーザーについての技術が開発され， その数年後には各種醉素、ビタミン，DNA，抗原なよ゙ の生体高分子へのレーザー照射の影響. さらに赫血球， 白血球，生体細胞についての作用も娭討さ㧈，生体への 安全性が確か力ら机た結果，1970年代からは臨床医学入 も応用が行わ机ることとなり，人体への责全な適用方法 もほぼ確立さ机ている”。

レーザーの被射体に対する作用としては1)熱作用， 2) 光化学的作用. 3 ) 光量子作用. 4 ) 電磁的作用の 4 つが考えら机ている。殺菌効果として㗢く作用として は, 熱作用上光化学的作用の 2 種類が主であるうと考元 られている”。

生物に対するレーザ一照射の試みについては、1963年 Saksらによりルビーレーザーが緑藻（Spirogyra）に 照射されたのが最初の報告である”。きの後、細菌に対 するレーザー照射の実験としては，1965年Klein放か，

P. aeruginosa, S. aureusにルビーレーザーを照射し たところ細菌の増殖が阻害されたと述べている゙。一方， 1966年Mc GuffらはS. aureus，P. aeruginosaに対す るルビー, He-Ne, Neodymiumの各種レーザーによる 殺菌効果を調べたが，いずれも明らかな殺菌効果は認め なかったとしている゙。1970年前半にはレーザー装置の 開発があまり進まなかったこともあり殺菌効果について の報告はほとんよ゙見当たらない。しかし，1980年代より 新たなレーザー装置の出現掞よび低出力のレーザーでも 細菌に色素染色を行うことにより殺菌効果の増強を期待 し得るようになったのでそ机による殺菌効果の有無、殺 菌効果があらわれるための照射出力の条件に関する報告 がなさ㣗るようになったう。

近年，医学領域における応用を目的としたレーザー技 術には大きな進歩があり，異なっだ種類のレーザーをよ り高出力で利用できるようになった。そこで著者は，新
しい方法によるレーザー照射が、現在の大きな課題であ るMRSA感染症の治療法として導入し得るか否かを娭 討するため，高出力〈数W）のアルゴンレーザー照射に よるMRSAに対する殺菌効果の有無㧍よびそのメ力二 ズムについて検討を行った。

\section{材料と方法}

\section{1. 殺菌と培養}

細菌は、グラム陽性菌であるMRSA 標準株いJCM 8702)，5種類のMRSA臨床分離株（a e ）上以下， 大阪医科大学微生物教室継代株であるMSSA (209P). Staphylococcus epidermidis. グラム险性菌も同教室 継代株であるE. coli JC-2，E，coli B，Pseudomonas aeruginosa, Serratia marcescensを用いた。

培地は, Heart infusion agar平板培地 (HIA, Difco). Heart infusion brorh液体培地 (HIB, Difco) O2 種 類を使用した。夷騃を行うにあたっては，HIA培地も

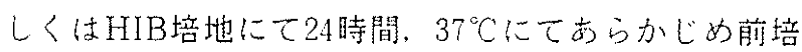
养した細菌老用いた。

2.レーザーの発振条件および発振方法

レーザー発振器としては、アルゴンレーザーくコーー レント社製，波長 $514 \mathrm{~nm}$ ) 在使用した。照射は連続発 振で行い，石英フライバー(值径 $400 \mu \mathrm{m})$ により導光 して、ファイバー先端にとりつけたハンドピースを使用 し非接触照射とした。HIA平板培地直上よりハンドピー 又先端までの距離在照射距離とし，照射条件〈照射出力， 照射時間，照射距離) 在各実騒においてき扛ぞ扟变化さ せ実験壳行った。

\section{3．アルゴンレーザーによる殺菌効果の有無}

すべての細菌をH I A 斜面培地にて前培養し、標準一 白金耳を採取してこれを $2 \mathrm{ml}$ の生食に浮遊させたもの を菌液とした。そこょり $150 \mu 1$ の菌液をとりだしHIA平 板培地表面上で一様となるようにコンラージ棒を用いて 塗布をした。照射距離が $20 \mathrm{~mm}$ となるようにハンドピース をスタンドで固定し，照射出力 $1 W$ にて，照射時間在 5 ， 10，15．20．25秒間之変化させレーザー照射を行った。 照射終了後に $37^{\circ} \mathrm{C}$ ． 24 時間培養して增殖阻止域の有無を 判定した。同操作を 2 回繰り返しその平均をとった。

4. 殺菌効果が表れる際のアルゴンレーザーの照射出 力之照射時間との関係

MRSA標隼株（JCM8702）２２種類のMRSA臨床分 離株（a， b ) , P. aeruginosa, E. coli B t使用 L。 上記と同様にHIA平板培地に一様に菌液老準布したの ちに，照射距離を $20 \mathrm{~mm}$ に固定した状態で照射出力を0.2. $0.4,0.6,0.8,1.0 \mathrm{~W}$, 照射時間を $10.20,30$ 秒之变 
化させて増殖阻止域の有無を判定した。

5.レーザー照射後の菌体の变化を透過型電子顕微鏡 にて観察

生食 $2 \mathrm{ml}$ に一白金耳のMRSA標準株を溶解して菌液 を作り，先端直径が $1 \mathrm{~mm}$ 前後のガラス棒を菌波に浸し． それをHIA 平板培地に接種し， $37^{\circ} \mathrm{C} ， 24$ 時間培養して， 均一にアルゴンレーザー照射ができる大きさのコロニー を作成した。照射出力，照射距離をそれぞれ $1 \mathrm{~W}, 10 \mathrm{~mm}$ に設定し，照射時間を 30 秒， 60 秒， 3 分と変化させて照 射した。レーザー照射後，同コロニーを白金耳にて採取 し電顕試料作成にとりかかった。1.5\% Acroleinと1.5\% Glutalardehydeのカコジル酷酸緩衝液で前固定し，

Osmium tetroxide (カコジル酶酸䌊衝液) で後固定 を行った。次に，アルコール脱水を行い，常法により包 埋, 超薄切片在作成した。超薄切片に酢酸ウラニル之鉛 の2 重染色を施し，透過型電子顕微鏡( H - 7000，日立) にて観察した。

菌体への熱および光化学的作用に上る菌体の形態的变 化について検討するため、エッペンドルフ型マイクロ チューブに入った50 $\mu$ lのMRSA標準株の菌液莸。ホッ トドライバスにて $65^{\circ} \mathrm{C} ． 15$ 分間加熱したもの㧍よび

HIA 寒天平板培地上にコロニーを作成しき㧈に殺菌灯

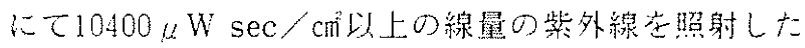
ものについて透過型電顕で観察した。

6.レーザー照射した菌体のアクリジンオレンジ染色 の萤光性の变化

次に、アルゴンレーザーが細菌の核酸に直接影響して いるかどうかを調べるためにアクリジンオレンジ染色の 䖯光性に関する実験在行った。 HIA 平板培地にMRSA 標準株のコロニーを作成してレーザーを照射した。照射

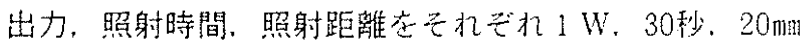

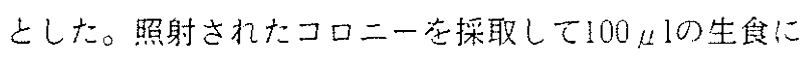
溶解し細菌浮遊液を作った。この液をプレパラートに1 滴滴下して乾燥させたのち，まずカル/ア固定波で20分 間固定し，0.5\%アクリジンオレンジ McIlvaine燐酸 緩衝液)で30分間染色後，同援衝液で洗浄したものを営 光顕微鏡で観察した。

\section{7.レーザー照射後のDNAの変化}

HIB液体培地 $50 \mathrm{ml}$ で前培養したMRSA 標準株を 3000 rpm, 10分間遠心集菌した。生食にて2回細菌老洗浄 し， $2 \mathrm{ml}$ の生食に溶解し菌液とした。エッペンドルフ

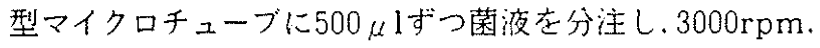
10分間遠心集菌して100 $\mu 10$ 生食にて細菌浮遊液老作成 した。これをシャーレ中央に滴下してなるべくアルゴン レーザーが菌液全体に照射さ机るようにした。照射出力。
照射距離を $2 \mathrm{~W} .10 \mathrm{~mm}$ と，照射時間を20分むるいは30 分とした。レーザー照射後. シャーレ上の細菌を再び $300 \mu 1$ の生食を用いて溶解し，エッペンドルフ型マイク ロチューブにもどして再度遠心して菌体由来のDNAを isoplant (ニッポンジーン社製)にて抽出，精製を行っ た。精製されたDNAをエチジウムプロマイド加 $10 \%$ ガロースゲルと2监アガロースゲルを用い電気泳動装置 (ミュービット：ミニゲル型)にて50Vの電圧のもよで 1 時間泳動を行った。電気泳動後. DNAのバンドのパ ターンを紫外線透過器にて観察し、ポラロイドで撮影し た。

対照実験としてDNAのSize marker Ampli Size DNA Size Standard, BIO-RAD)にアルゴンレー ザーを照射し，照射前後のDNAの变化を2\%アガロー スゲル電気泳動にて調べた。

\section{結 果}

\section{アルゴンレーザーによる殺菌効果の有無}

図1は，アルゴンレーザーの照射出力1.0W，照射距 離20mnに书いて照射時間老5，10．15，20．25犁之変化 させた時のHIA寒天培地上での増遖阻止域の有哭葆示 したもので索る。こ机に上り照射時間が5秒の時点で境 界が不鲜明で南るが增犆阻止域の形成点瑟め，10梨では すべての細菌に明的な增殖阻止域堂認めた。

殺菌効果があらわれる際のアルゴンレーザーの照射出 カと照射時間との関係

照射距離を $20 \mathrm{~mm}$ として，照射出力を0.2，0.4，0.6. 0.8．1.0W上变化させ，また照射時間も10，20．30秒之 照射時間

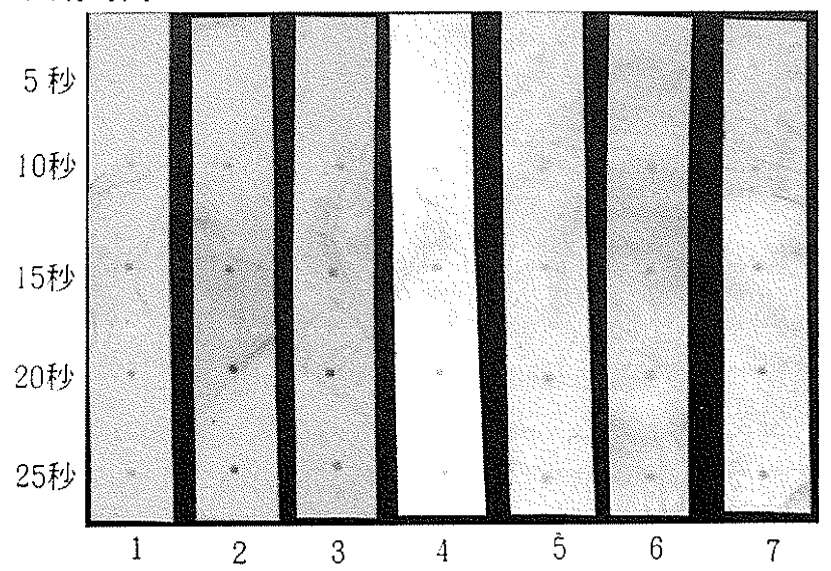

図 1 各種細菌へのアルゴンレーザー照射後の增殖阻止 域の形成

1.MRSA (JCM-8702) 2. MRSA(臨床分離株)

3.S. epidermidis 4. MSSA (209P)

5. P. aeruginosa $\quad$ 6. E. coil JC-2

7. E. coil B 
表 1 殺菌効果に及ぼす照射出力と最小必要照射時間との関係

\begin{tabular}{l|r|r|r|r|r}
\hline \multirow{2}{*}{ 菌 照射出力 } & \multicolumn{5}{|c}{ 旺小必要照 射時間 (秒 ) } \\
\cline { 2 - 6 } MRSA (JCM-8702) & $0.2 \mathrm{~W}$ & $0.4 \mathrm{~W}$ & $0.6 \mathrm{~W}$ & $0.8 \mathrm{~W}$ & $1.0 \mathrm{~W}$ \\
MRLA a & $>30$ & 30 & 20 & 10 & 10 \\
MRSA b & $>30$ & 30 & 20 & 10 & 10 \\
P. aeruginosa & 20 & 20 & 10 & 10 & 10 \\
E. coli B & $>30$ & 30 & 20 & 10 & 10 \\
Serratia. M & $>30$ & 30 & 20 & 10 & 10 \\
\hline
\end{tabular}

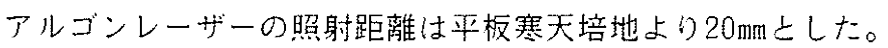

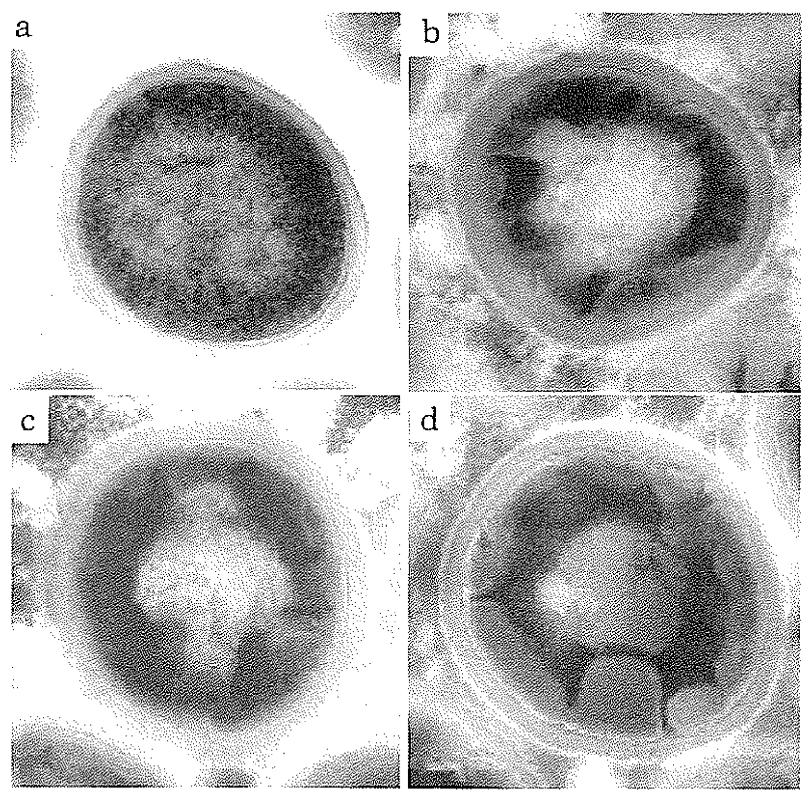

図 2 アルゴンレーザーの照射時間を变化させた時の菌 体の透過電顕所見
a. 非照射 b.照射時間 30 秒 c，照射時間 60 秒
d. 照射時間 3 分

変化させたところ表 1 の結果が得ら机た。こ机よりグラ 么陽性菌であるMRSA標準株，MRSA臨床分離株とグ ラム陰性菌であるE。 coli B. Serratia，Mの間には。 増殖阻止域が諗められた際のレーザーの照射条件に明ら かな差はなかった。すなわち照射時間が0.2Wの時には。 增殖阻止域が認められるまで少なくとも30秒以上のレー ザー照射が必要であり，0.4Wでは30秒，0.6Wでは20秒， $0.8 \mathrm{~W} て ゙ は 10$ 秒の照射時間にて增殖阻止域の形成がみら れた。しかし，P. aeruginosaに拈いては．2Wの出力 でも照射時間10秒で増殖阻止域が認めら机，他の細菌に 比ベてアルゴンレーザーにより殺菌されやすいことがわ かった。

レーザー照射後の菌体の変化を透過型電子顕微鏡にて 観察

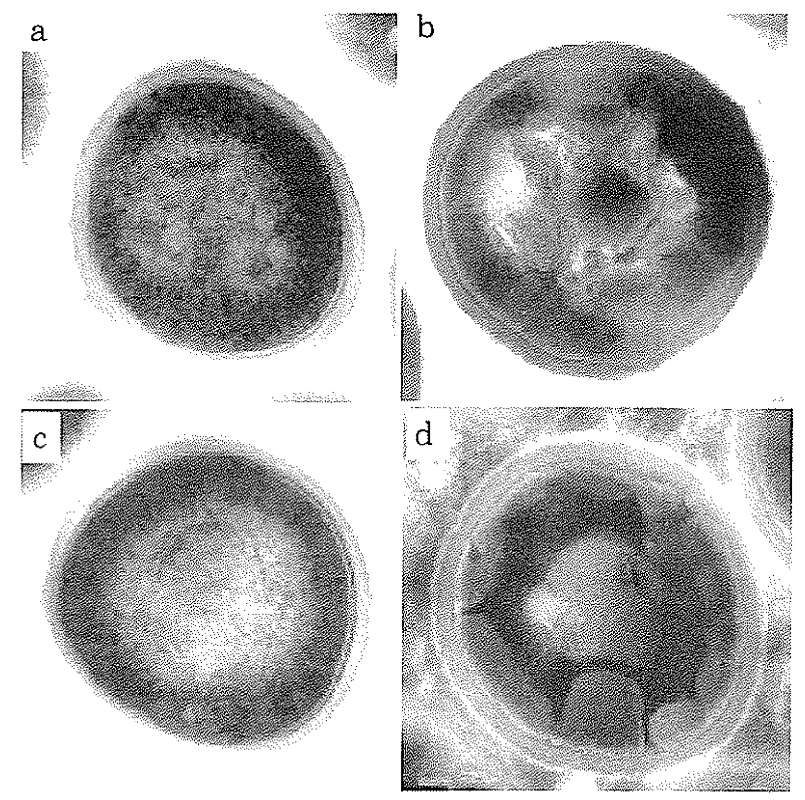

図 3 アルゴンレーザー照射，紫外線照射，熱処理後の 菌体の透過電顕所見
a. 非照射 b. 熱処理 c. 紫外線照射
d.レーザー照射

レーザー照射前（図 2 a) では菌体の中心部は電子密 度が低く。その周辺部の細胞質は電子密度が高くなって 扮り，また外膜㧍よび細胞質膜は明瞭に認められた。照 射時間が30秒（図 2 b) に抽いては主に，細胞質と核中 心部に電子密度の低下した部分と高くなった部分とが混 在した不規則な構造が認められた。さらに照射時間が 60 秒（図２ｃ）になると細胞貿，核様体付近に線状の棈造 物が見ら㧈，細胞膜は不明瞙となり、細菌壁の膨化傾问 が認められた。照射時間が 3 分（図 2 d）では細菌壁は 覌縮し，細胞膜上細胞壁の離開する像が見られ，細胞質 は雲㖙状の構造物により不規則よなるのが観察されだ。

MRSAの熱処理後の变化（図 3 b）在同栐に透過型 電影で観察し、レーザー照射前（図 $3 a$ ）、レーザ一照 射後（図 3 d）上比较したところ，細胞盺，核様体 

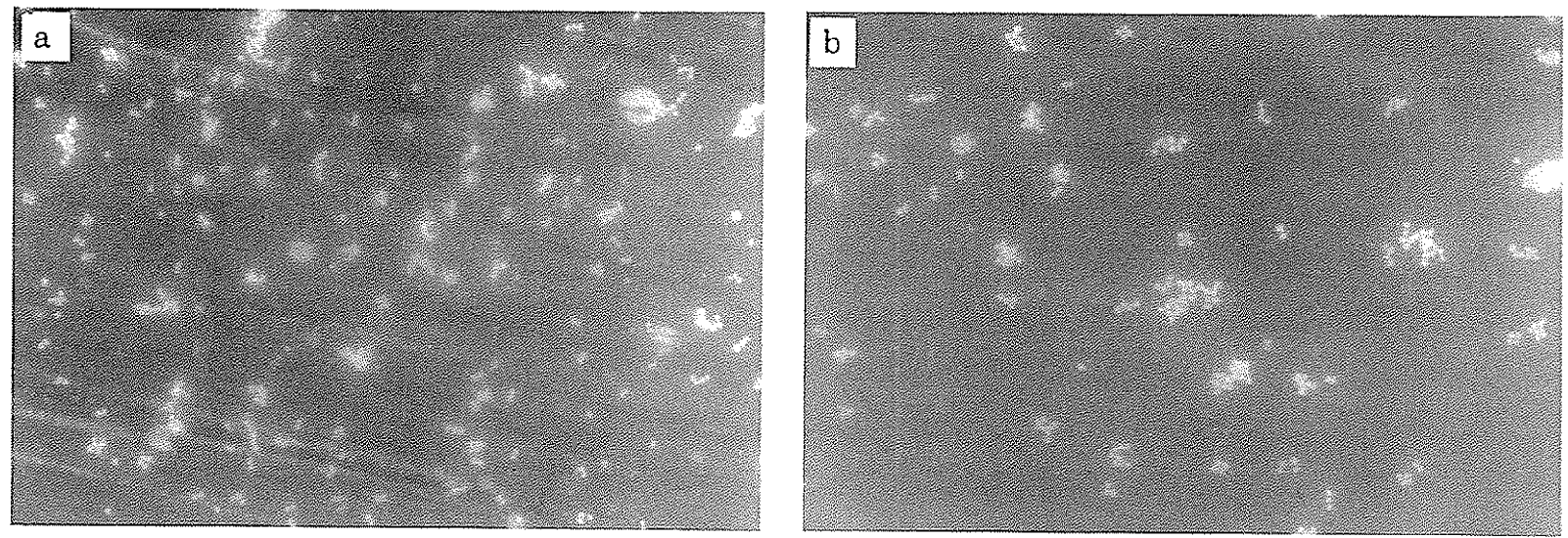

図4 アルゴンレーザー照射による菌体の蛍光性の賕化

a.レーザー照射前 b.レーザー照射後

付近にアルゴンレーザー照射後と同様に雲絮状の構造物 がみられた。一方，紫外線（図 $3 \mathrm{c}$ ）では全体的として 細胞質内で電子密度が多少増した程度で細菌壁に变化は 認められなかった。

レーザー照射した菌体のアクリジンオレンジ染色の蛍 光性の变化

アルゴンレーザーを照射した細菌と非照射の細菌との アクリジンオレンジ染色の蛍光性を比較したよころ両者 に著しい鸴光性の变化は観察されなかった（図 4)。

さらにDNA自体の变化の有無を調べるために，アル ゴンレーザー照射後のMRSA標準株よりDNAを抽出, 精整し、アガロースゲル電気泳動にてアルゴンレーザー 照射前後のDNAのバンドのパターンを比較した（図

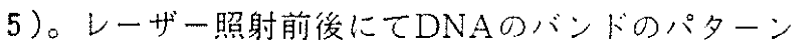
に明らかな変化はなく、さらにSize markerに直接アル ゴンレーザーを照射し同様な方法で観察したところこれ に㧍いても変化は見られなかった。

\section{考 察}

1960年にルビーレーザーによる世界最初のレーザー発 振が成功し，生物に対しては1963年にSaksらが緑藻に ルビーレーザーを照射し，細胞レベルにおける形態学的 変化を光学顕微鏡にて観察したのが最初である゙。1965 年 KleinらはSerratia, S. aureus, Pseudomonas. Pneumococcus, Aspergillus nigerにルビーレーザー を照射したところ60〜250Jの照射エネルギーに打いて 殺菌効果を認め, 菌体外色素を産生するSerratia, Pseudomonasにおいては $60 \mathrm{~J}$ をこたころより色素尘生能 が一時的に滅弱したと報告している゙”。その後. He-Ne laserが開発され，それによる殺菌効果についても検討 されたが，発振器自体が低出力であるため細菌に色素処 理をしてからでないと十分な殺菌勃果が得られない上述

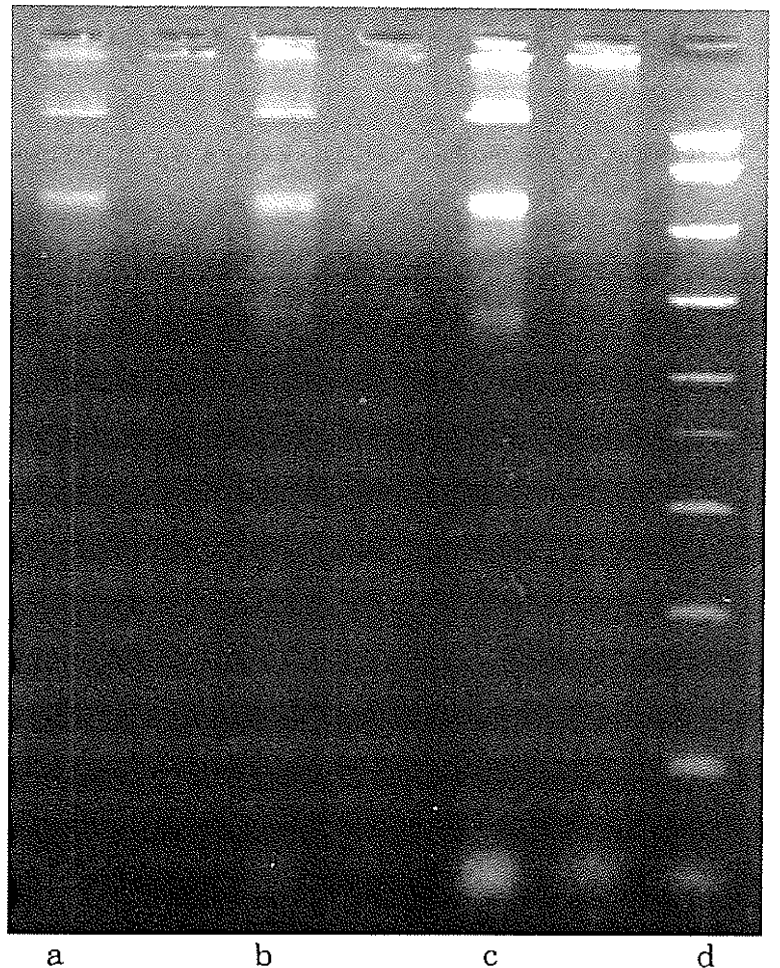

図 5 アルゴンレーザー照射と非照射よの間の $2 \%$ ア ロースゲル電気泳動によるDNAのバンドパター ンの比較
a. 照射時間20秒
b. 照射時間 30 秒
c. 非照射
d.サイズマーカー

ベられているう。

一方，今回の奏験に使用したアルゴンレーザーと同様 に高出力レーザーである carbon dioxide laserによる 殺菌作用についての研究は，蒾科領域に用いる器材の消

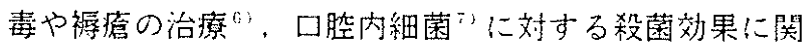
するものはみらるが，その殺菌のメカニズムに関する梚 討はほとんど触机ら机ていない。アルゴンレーザーにつ いては1988年柳川らがP. aeruginosa、 E. coil. S. aureusにレーザーを照射して殺菌効果の有無について娭 
討しており，その中で菌体外色素を産生するP. aeruginosaが最も殺菌されやすかったと報告しているが，殺 菌のメカニズムに対する記述はなされていない゙。今回 の実験では高出力レーザーであるアルゴンレーザーによ る殺菌勃果の有無とそのメカニズムについて，主に形態 学的な面より考察老行った。

まずアルゴンレーザー単独で殺菌効果が認めら机るか

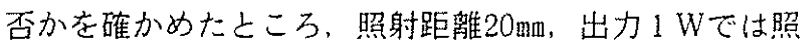
射時間が 5 秒以上から增殖阻止域の形成がみられアルゴ ンレーザー単独で十分に殺菌効果があることを認めた。 また菌体外色素を産生するP. aeruginosa以外では，細 菌の種類（グラム陽性, グラム陰性菌）により增殖阻止 域の形成に明らかな相違はみられなかった。このことか ら, 細菌壁の構成成分の遣いにより特に殺菌勃果に相違 はないものと考えら扎たしかし，菌体外に色素産生能 を有するP. aeruginosaに扰いては照射出力を1Wより 低下させて照射した場台，他の細菌に比べてより短い照 射時間にて殺菌効果が現机ている。この理由としては。 P. aeruginosaの産生する菌体外色素である緑色のpyocianinなよ゙の色素によりレーザーの殺菌効果が增幅さ れたものと考えられる。このことはすでに柳川らのアル ゴンレーザーを用いた実験》， OkamatoらによるHe-

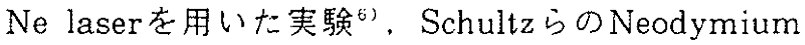
YAG laserを用いた実験”においても同様の報告がな さ机ている。著者は，菌体外に赤色心色素を産生する Serratia marcescensにおいてもP. aeruginosaと同じ ようにレーザーによる殺菌効果の增幅が認めら扟るので はないかと予想したが，他の細菌と殺菌効果においては 差はなかった。この理由はP. aeruginosaに比べて色素 の座生量自体が非常に少なく，さらに細菌を生食に溶解 する過程においてより色素が希釈されることでアルゴン レーザーによる色素を介した殺菌增強効果が現㣗にく かったものと思われた。

照射出力と照射時間よの関係で，照射出力が大きくな るにつれて殺菌効果が出現する時間はより短くて済むこ とがわかった。SchultzらはNeodymium-YAG laser を用いてS. aureus，E. coliを殺菌するには，1.667 J $\mathrm{cm}^{2}$ 以上のエネルギーが必要であると述べており"，我々 の実験からも殺菌効果が現れるのには市る一定以上の工 ネルギーが必要であると思われた。

次に，アルゴンレーザーによる殺菌のメカニズムにつ いて透過型電子顕微鏡を用いて形態学的に検討い1いし たところ，照射出力 $1 \mathrm{~W}$ ，照射時間が30秒では主に細胞 質に变化がみられ，細菌壁の構造は比較的保たれていた。 さらに，照射時間が長くなるにつ扟て細菌壁にも変化が
みられるようになり，照射時間が 3 分になれば細胞膜之 細菌壁との間に間隔が生じて原形質分離を生じていた。 以上の結果よりアルゴンレーザーによる菌体の変化はま ず細胞質にて始まり，それに遅れて細菌壁に変化が現れ てくるよ思わ扎た。この变化については，次の2つのこ とが考えられる。一つは，アルゴンレーザー照射の影響 がまず細胞質にあらわ机，次に少しおく机て細菌壁にも 同様な影響が現机たという考えでする。他の一つはアル ゴンレーザーが細胞質のみに影響を与え。そ机により障 害を受けた細胞筫の代謝経路に变化が生じたことにより 細菌壁の生合成が 2 次的に变化したという考えである。 今回の実験からは，前者の方がより説明が行い易い。そ れは，照射時間が30秒に执いて細菌壁の変化がほとんよ゙ みられないのに比べ60秒では著しく变化が起こっており． アルゴンレーザーによって細胞啠筫の代謝経路に変化が生 じたとしてもこれほど短時間に細菌壁に影響が生じるよ は考えにくい。従ってアルゴンレーザーにおいては，細 胞筫のはうが細菌壁に比べてレーザーがより高率に吸収 され影響が出やすいものと考えら扎る。

細菌に対するレーザ一の作用として，現在、考えら机 ているのは主として熱作用と光化学的作用の 2 つであ る゙。アルゴンレーザーによる殺菌作用についてそのよ゙ ちらがおすに関与しているかを調べるため，熱作用のモ デルよして細菌を $65^{\circ} \mathrm{C} ， 15$ 分間加熱した後の菌体の变化 を，一方，光化学的作用のモデルとしては菌体に紫外線 を照射した後の变化を電顕にて観察した。熱作用のモデ ルでは主に, 細菌壁に接している細胞質付近に電子密度 の高い部分と低い部分とが混在しているのに対し、アル ゴンレーザーでは同㥞の变化が菌体の中心部付近に起 こっている。このことは，外部から菌体に熱が加わった 場台上菌体内部にて熱が発生した場台との違いによるも の上思われた。光化学的作用のモデルである紫外線照射 後の菌体の変化はアルゴンレーザ一照射後上は明らかに 遠っていた。従ってアルゴンレーザーによる殺菌作用と しては主に熱作用による可能性が高い上考えられ、しか も熱の発生する場所としては，レーザ一光が菌体内で昅 収されることにより熱が発生しているのに対して，熱作 用モデルの場台は主に外部から加えら行た熱により菌体 に変化が起こっているという点が形態学的な差として現 扎ている可能性がある。我々の行った予俑実騃による上 MRSAの場台. $65^{\circ} \mathrm{C} て ゙ 10$ 分間加熱することにより十分 な殺菌効果が得られたこよにより，少なくとも照射出力 $0.2 W$ ，照射時間30秒の照射条件にて培地表面上の温度 は $65^{\circ} \mathrm{C}$ 以上の温度まで上昇している可能性がある。しか し，レーザーの照射出力および照射時間の変化による培 
地表面上の正確な温度測定は，技術的にも困難上思わ机 たので今後, 検討の必要があると思われる。

アルゴンレーザーが細胞質のよ゙の部分に抽もに作用し て殺菌効果が生じているかについては、アクリジンオレ ンジ染色の蛍光性の变化とDNAのバンドパターンの変 化を観察したが, 両者ともアルゴンレーザー照射前後で 変化はなかった。このことからアルゴンレーザーは紫外 線のように光化学的作用に上りDNAの結合に变化をお こす可能性は少なく，またDNAは比較的高温にも安定 であるこよよりアルゴンレーザーによる熱作用により変 化は生じにくいもの上考えられる。以上の結果より核酸 よりはるかに熱による影響をうけやすい細胞質内の蛋白 質などに対してアルゴンレーザーが熱作用を及ぼし、殺 菌効果が現机ているものと推測さ记る。今回. 著者が行っ たようなレーザー照射後の菌体の形態学的変化に関して 述べているものは見当たらないが, Adkissonらはアル ゴンレーザーをラットの心筋細胞に照射してその变化を 透過型電顕にて観察している12。その報告では、レー ザーを照射された部分のミトコンドリアの内膜には濃染 されたスポットが観察され，そ扎以外の領域には变化が みられなかったとしている。またその濃染した部分は。 アルゴンレーザーが同部で吸収され熱エネルギーに变化 したことにより生じたものであろうと推测している。ま たStorbらも上皮細胞や線維芽細胞には染色をほどこし てルビーレーザーを照射し，細胞が受ける損傷の程度を 透過電顕の所見より分類している13)。この奏験におい てもミトコンドリアには強く濃染される部分が存在し細 胞膜には変化が及んでいない上している。ミトコンドリ アが強く濃染されるのは熱による变化であるとする点は 著者の考えと一致するが，今回，照射したものが細菌で あることから心筋細胞に存在するようなミトコンドリア は存在しないものの，それに代わる細胞質内の蛋白質を 材料とする器官に変化が現机ているものと考えられる。

\section{結 論}

アルゴンレーザーによる殺菌勃果およびそのメカニズ ムについて述べた。アルゴンレーザーは他の低出カレー ザーに比べ，細菌に色素を反応せずに照射しても強い殺 菌効果を有していた。そして，その殺菌のメカニズムは おもに熱作用によるものであり，その作用する主たる部 分は細胞質で，細菌壁の変化は細胞質内で生じた熱が 2 次的に作用したものであろうと考えられた。細胞質内で 生じた熱は細菌のDNAの結合パターンに直接影響を与 えるよりも蛋白質に变化をおよぼすことにより細菌を死 隇させるものと思われた。
稿を終えるに臨み、ご指導、御校閲を睗りました小野 村敏信教授，中井益代教授に深謝します。また，終始银 切なる御指導, 御鞭撻をいただきました佐野浩一助教授. 後藤俊幸講師，米沢卓実非常勤講師に感謝をいたします。

\section{参考文献}

1) レーザー医学（渥美和彦編）中山畫店(1980)

2) Saks NM, Roth CA : Ruby laser as a microsurgical instrument. Science : $141:$ 46-47. 1963.

3) Klein E, Fine S, Ambrus J, Cohen E, et al : Interaction of laser radiation with biologic systems. Studies on biologic systems in vitro. Fed Proc ; 24 : 104-110.1965.

4) Mc Guff PE, Bell EJ : The effect of laser energy radiation on bacteria. : Med Biol ; 16 : 191-194, 1966.

5) Okamoto $\mathrm{H}$, Iwase T, Morioka T: Dye mediated bactericidal effect of $\mathrm{He}-\mathrm{Ne}$ laser irradiation on oral microorganisms. Lasers Surgery Med ; $12: 450-458,1992$.

6) Stellar S, Meijer R Walia S, Mamoun S : Carbon dioxide laser debridement of decubitus ulcers. Ann. Surg, ; 179 (2) : 230-237. 1974.

7 ) Dedrich DN, Vaughn AS, Tulip J, Zakariasen KL,et al : Comparative bactericidal exposure for selected oral bacteria using carbon dioxide laser radiation. Laser Surgery Med ; 10 : 591 594. 1990.

8 ) Yanagawa T. Hashimoto $\mathrm{K}$ : Growth inhibitory cffect of Ar-laser to Pseudomonas aeruginosa. J Jpn Soc Laser med, 9 (3) : 201-204,1988.

9 ) Schultz RJ. Harvey GP. Fernandez-Beros ME, Krishnamurthy $\mathrm{S}$, et al : Bactericidal effects of the neodymium : YAG laser in vitro study : Laser Surgery Med, 6 : 445-448, 1986.

10) Suganuma A: The plasma membrane of staphylococcus treated with $\mathrm{HCl}$ solutions: J. Cell. Biol. 21 : 290-293, 1964.

11) Suganuma A Further studies on the plasma membrane of staphylococcus aureus : J. Cell, Biol : $30: 208-210,1966$.

12) Adkisson PK, Dusan B : Argon laser microirradiation of mitochondriain rat myocardial cells in tissue culture : Jounal of Molecular and Cellular Cardiology ; 5 : 559-564. 1973. 
13) Storb R. Amy RL, Wertz AK, Fauconnier B. et al: An electron microscope study of vitally stained single cells irradiated with a ruby laser microbeam : J. Cell. Biol., 31 ; 11-29, 1966. 